
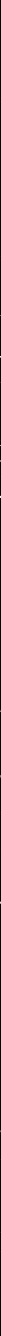

$1 \quad-$
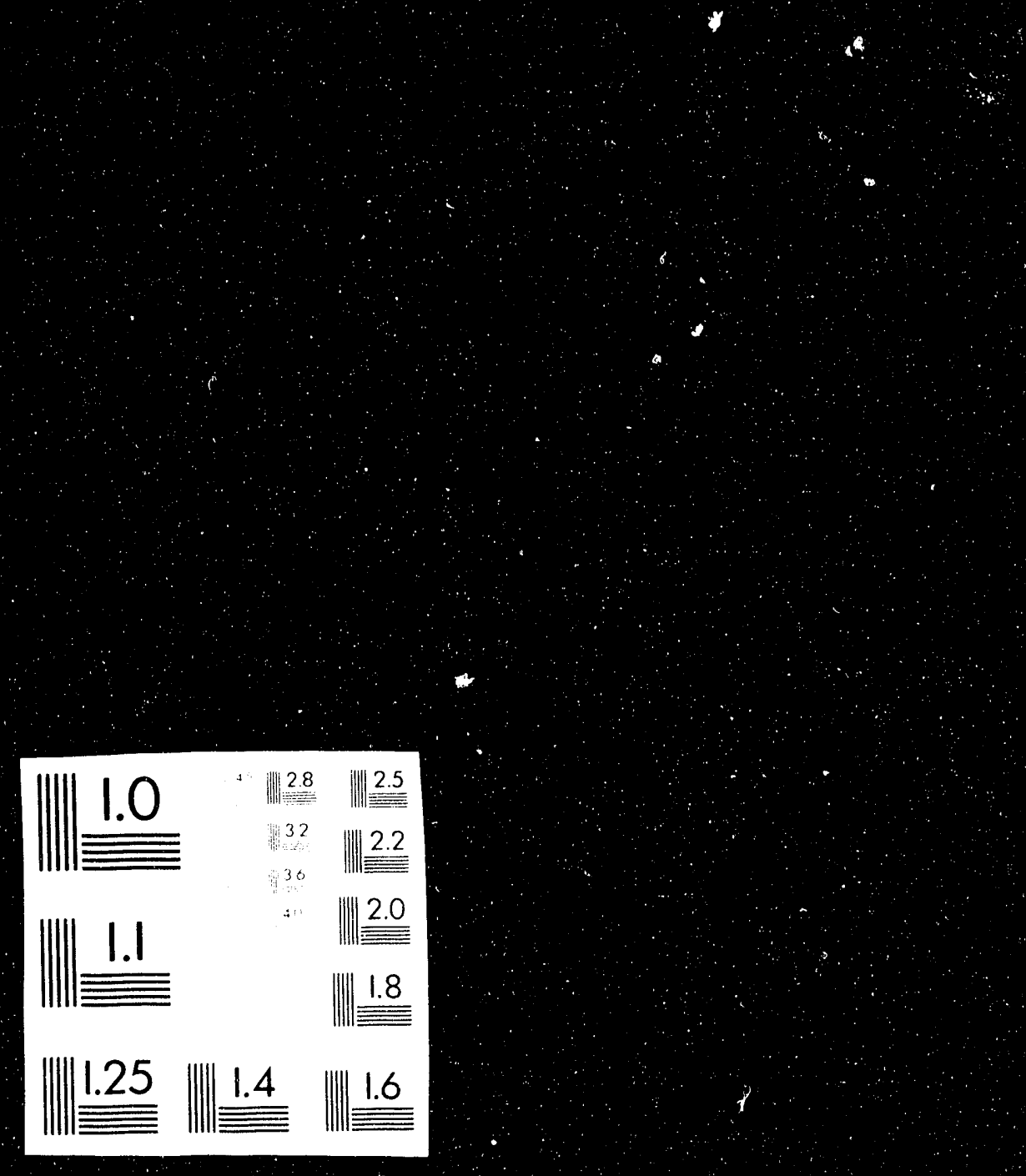

i. - 


\section{Market Enhancement of Shale Oil - The Native Products Extraction Technology}

\section{Topical Report}

October 1991

Work Performed Under Cooperative Agreement No.: DE-FC21-90MC27084

For

U.S. Department of Energy

Office of Fossil Energy

Morgantown Energy Technology Center

Morgantown, West Virginia

By

Occidental Oil Shale, Inc.

Steamboat Springs, Colorado

and

James W. Bunger and Associates, Inc.

Salt Lake City, Utah 


\section{DISCLAIMER}

This report was prepared as an accourt of work sponsored by an agency of the United States Government. Neither the United States Government nor any agency thereof, nor any of their empioyees, makes any warranty, express or implied, or assumes any legal liability or responsibility for the accuracy, completeness, or usefulness of any information, apparatus, product, or process disclosed, or repiesents that its use would not infringe privately owned rights. Reference herein to any specific commercial product, process, or service by trade name, trademark, manufacturer, or otherwise does not riccessarily constitute or imply its endorsement, recommendation, or favoring by the United States Government or any agency thereof. The views and opinions of authors ex. pressed herein do not necessarily state or reflect those of the United States Government or any agency thereof.

This report has been reproduced directly from the best available copy.

Available to DOE and DOE contractors from the Office of Scientific and Technical Information, P.O. Box 62, Oak Ridge, TN 37831; prices available from (615)576-8401, FTS 626-8401.

Available to the public from the National Technical Information Service, U.S. Department of Commerce, 5285 Port Royal Rd., Springfield, VA 22161. 


\section{Market Enhancement of Shale Oil - The Native Products Extraction Technology}

Topical Report
DOE/MC/ $27084--3038$

DE92 001112

James W. Bunger and Associates, Inc.
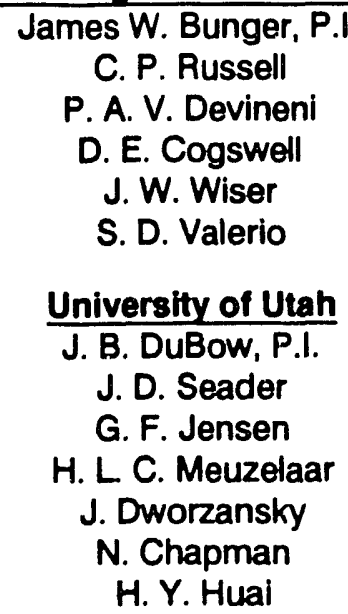

Work Performed Under Cooperative Agreement No.: DE-FC21-90MC27084

For

U.S. Department of Energy

Office of Fossil Energy

Morgantown Energy Technology Center

P.O. Box 880

Morgantown, West Virginia 26507-0880

By

Occidental Oil Shale, Inc.

P.O. Box 880408

Steamboat Springs, Colorado 80488

and

James W. Bunger and Associates, Inc.

P.O. Box 520037

Salt Lake City, Utah 84152-0037

October 1991 


\section{Contents}

Executive Summary $\ldots \ldots \ldots \ldots \ldots \ldots \ldots \ldots \ldots \ldots \ldots \ldots \ldots \ldots \ldots \ldots \ldots \ldots \ldots \ldots \ldots$

Purpose and Objectives $\ldots \ldots \ldots \ldots \ldots \ldots \ldots \ldots \ldots \ldots \ldots \ldots \ldots \ldots \ldots \ldots \ldots \ldots$

Accomplishments $\ldots \ldots \ldots \ldots \ldots \ldots \ldots \ldots \ldots \ldots \ldots \ldots \ldots \ldots \ldots \ldots \ldots \ldots \ldots \ldots \ldots$

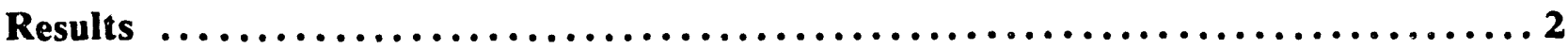

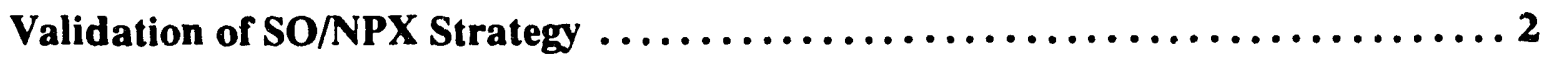

Demonstration of Analytical and Engineering Data Methodology $\ldots \ldots \ldots \ldots \ldots 4$

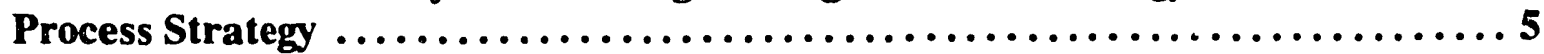

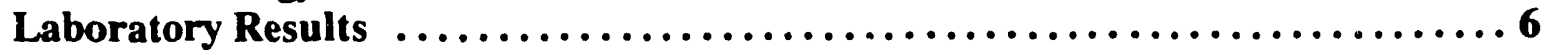

Shale Oil NPX Product Slate $\ldots \ldots \ldots \ldots \ldots \ldots \ldots \ldots \ldots \ldots \ldots \ldots \ldots \ldots \ldots \ldots \ldots$

Development of Market Strategy $\ldots \ldots \ldots \ldots \ldots \ldots \ldots \ldots \ldots \ldots \ldots \ldots \ldots \ldots$

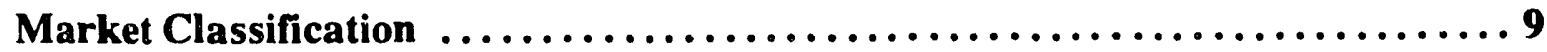

Market Size ............................................... 10

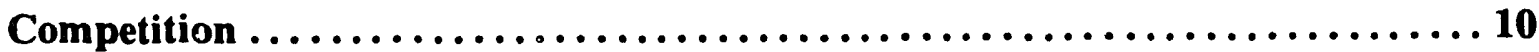

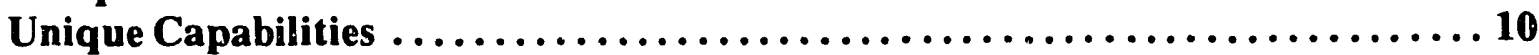

Market Penetration..$\ldots \ldots \ldots \ldots \ldots \ldots \ldots \ldots \ldots \ldots \ldots \ldots \ldots \ldots \ldots$

Economic and Profitability Estimates $\ldots \ldots \ldots \ldots \ldots \ldots \ldots \ldots \ldots \ldots \ldots \ldots \ldots$

Future Development $\ldots \ldots \ldots \ldots \ldots \ldots \ldots \ldots \ldots \ldots \ldots \ldots \ldots \ldots \ldots \ldots \ldots \ldots \ldots \ldots \ldots$

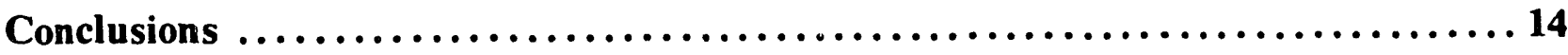

References $\ldots \ldots \ldots \ldots \ldots \ldots \ldots \ldots \ldots \ldots \ldots \ldots \ldots \ldots \ldots \ldots \ldots \ldots \ldots \ldots \ldots \ldots \ldots$

Acknowledgements $\ldots \ldots \ldots \ldots \ldots \ldots \ldots \ldots \ldots \ldots \ldots \ldots \ldots \ldots \ldots \ldots \ldots \ldots \ldots \ldots \ldots$ 


\section{Executive Summary}

Shale Oil Native Products Extraction technology (SO/NPX), shows strong promise for enhancing the marketability of shale oil. This technology, if fully developed, promises to accelerate development of vast resources of oil shale present in the United States.

SO/NPX is a strategy for selective, non-destructive separation of shale oil into fractions which possess high market value. The strategy has been validated through laboratory separation of raw shale oil.

A preliminary product slate, targeting more than $90 \%$ of the shale oil barrell for high-value markets has been identified. Markets have been surveyed for volume and product price.

A market strategy has been devised which classifies SO/NPX products by end use and addresses the approach for market penetration. Maximum economic enhancement of a commercial shale oil facility is anticipated because a large percentage of the SO/NPX product slate addresses large, well-established markets.

Economic and profitability estimates reveal a strong profit potential for SO/NPX. A DCF-ROI of $>30 \%$ is projected for the all-equity case. The results suggest that SO/NPX would be profitable even for raw shale oil costs of up to $\$ 40 / \mathrm{bbl}$.

The SO/NPX technology promises significant economic enhancement for shale oil production facilities of 25,000 bbls/day. 


\section{Market Enhancement of Shale Oil - The Native Products Extraction Technology}

\section{Purpose anoi Objectives}

This work was conducted by James W. Bunger and Associates, Inc. (JWBA), under Cooperative Agreement No. DEFC21-90MC27084 between the U. S. Department of Energy (DOE) and Occidental Oil Shale, Inc. (OOSI). It was jointly funded by local and state governments in Colorado, the DOE and OOSI. The development of a Proof-of-Concept oil shale facility (the Project), that would demonstrate all aspects of the technology required for commercial operations.

Commercialization of Western Shale Oil may be enhanced through separation and processing for products with high market value. The separation techniques, primarily distillation, extraction and adsorption processing, are low cost in comparison to the incremental value added to the product slate.

JWBA has initiated the development of Shale Oil Native Products Extraction (SO/NPX) technology to achieve this economic enhancement. The program planning phase has been designed to demonstrate the technical feasibility of SO/NPX, to establish the basis for process research and development and to assess the market and economic feasibility of the strategy.

The overall objective of this work was to assess the feasibility of enhancing shale oil commercialization through SO/NPX technology. Specific objectives were:
1. To determine the properties and characteristics of fractions isolable from shale oil utilizing separation sequences which are based on thermodynamic considerations;

2. To identify product streams of market value for promising technology development;

3. To conduct technology development studies leading to a shale oil extraction and processing sequence which promises economic enhancement of shale oil commercialization;

4. To develop an analytical methodology and model for obtaining engineering design data required for process development; and

5. To estimate the economics of SO/NPX including the potential for enhancing the profitability of a commercial-scale shale oil MIS retort.

\section{Accomplishments}

The following tasks were conducted:

1. A barrel of shale oil was distilled into distillate and residue fractions.

2. The distillates, residue and separated fractions were characterized according to important chemical and physical properties.

3. Shale oil fractions were separated by commercially meaningful process ap- 
proaches using a thermodynamically logical scheme.

4. Products from the separation sequence were characterized, analyzed by sophisticated compositional analysis techniques and process outputs were matched to their potential market application.

5. The U.S. commodity and specialty products markets were surveyed for volume and price and the quantitative yield of products present and isolable from shale oil was estimated.

6. Capital and operating costs for manufacture of the product slate were estimated. Costs for transportation and distribution of products were ar'ded, and a profitability analysis for Si)/NPX was performed.

\section{Results}

\section{Validation of SO/NPX Strategy}

Validation of SO/NPX required the answer to four important questions. These were:

1. Is a description of shale oil by distributed functions of molecular weight a valid basis for development of the technology?

2. Are currently available and low-cost separation processes effective in separating shale oil according to parameters correlatable to these distributed functions?

3. Do the process streams produced by a thermodynamically logical separation scheme promise market potential?

4. Are the projected economics suffi- ciently positive to encourage further development?

Those questions were answered by a focused experimental program, supported by engineering and economic analysis.

A barrel of surface retorted (solids downflow), shale oil was distilled in a tentray column operated in a steam-stripping mode. Figure 1 shows the material balance for the distillation. The figure shows that three distillates and a residue fraction were prepared for study.

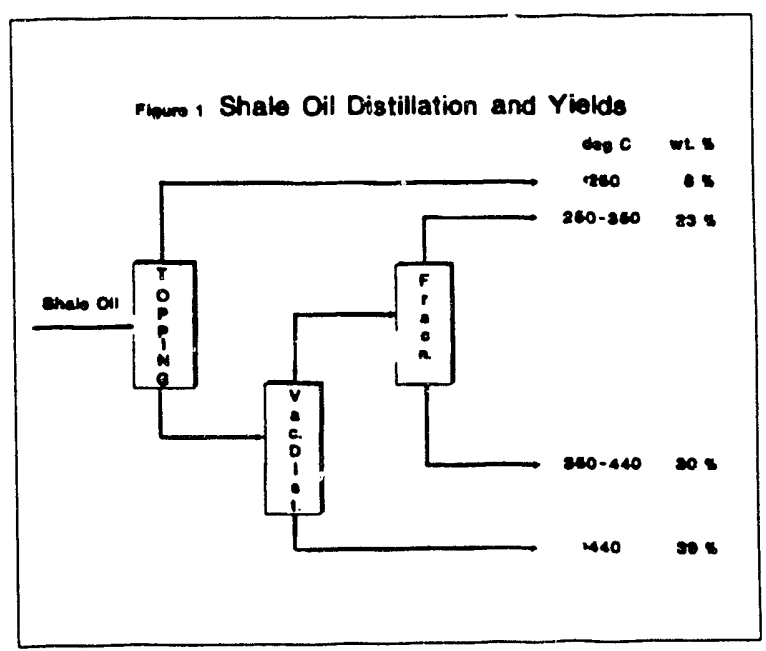

The whole shale oil and distillate fractions were characterized by elemental analysis, physical properties, GC-MS and FTIR. The boiling point distributions of the fractions were confirmed by simulated distillation. An important element of any industrial process is the material balance for the constituents. For purposes of this study, both mass and elemental balances were monitored throughout.

Figure 2 shows the distribution of the heteroatomic elements throughout the shale oil range. These distributions have been generated by curve-fitting the data to appropriate mathematical functions, 
thereby allowing for accurate interpolation and extrapolation of the data. The distribution of heteroatoms is important for determining concentrations of functionalized intermediates. Elemental analysis may also be used as an overall measure of the effectiveness of a given separation.

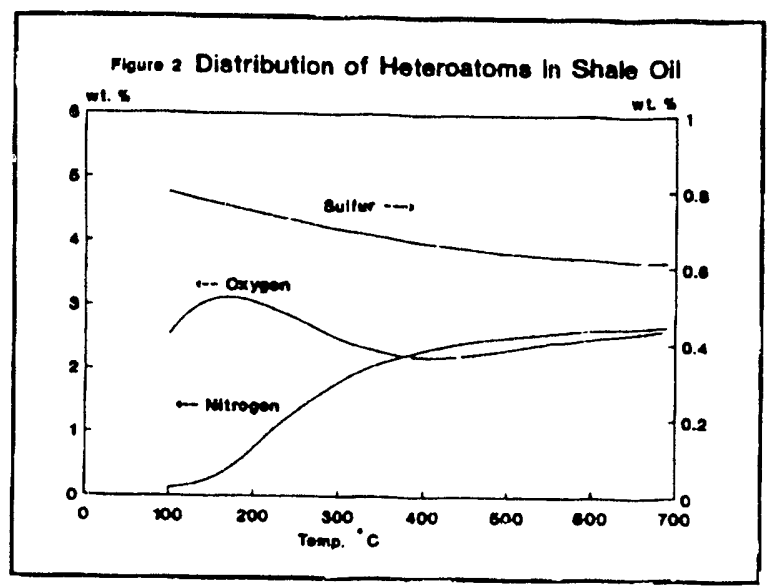

Figures 3(a-d) show the total ion chromatograms (TIC) of the four distillate fractions. These data were obtained at the University of Utah microanalysis laboratory. The TIC data show the quality of the distillation and detail of the spectral response. From this data specific ion chromatograms can be generated for tracking the separation fate of specific molecular systems.

For the characterization of shale oil by distributed functions, molecular weight was chosen as the independent variable. Although boiling point is an easier property to measure, molecular weight is more fundamentally related to the properties of molecules. Molecular weight is determined by parent peak mass spectroscopy.
Figure 3.

Total Ion Chromatogram of Shale Oil Distillate Fraction

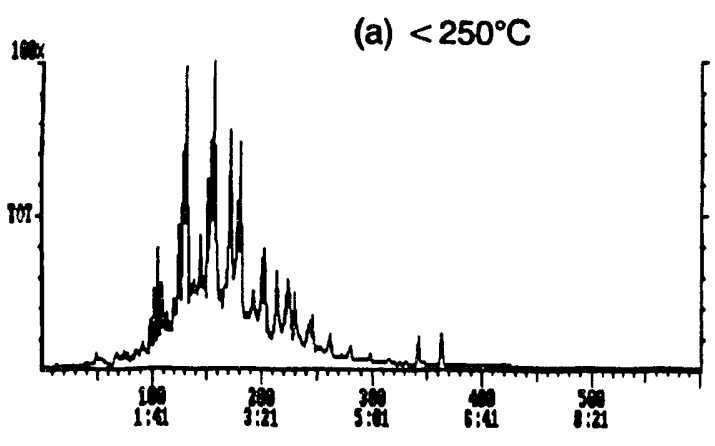

(b) $250-350^{\circ} \mathrm{C}$

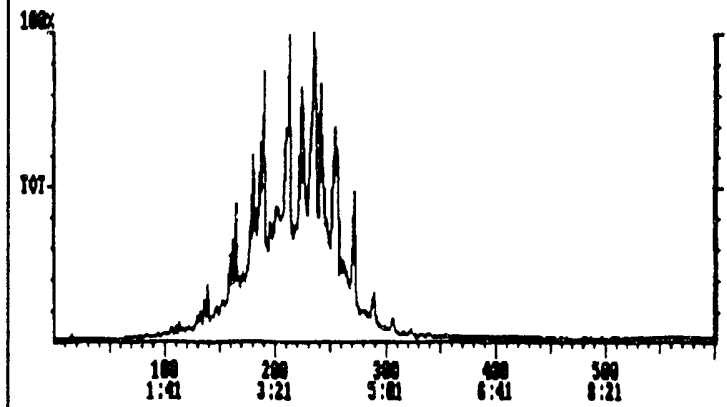

(c) $350-440^{\circ} \mathrm{C}$
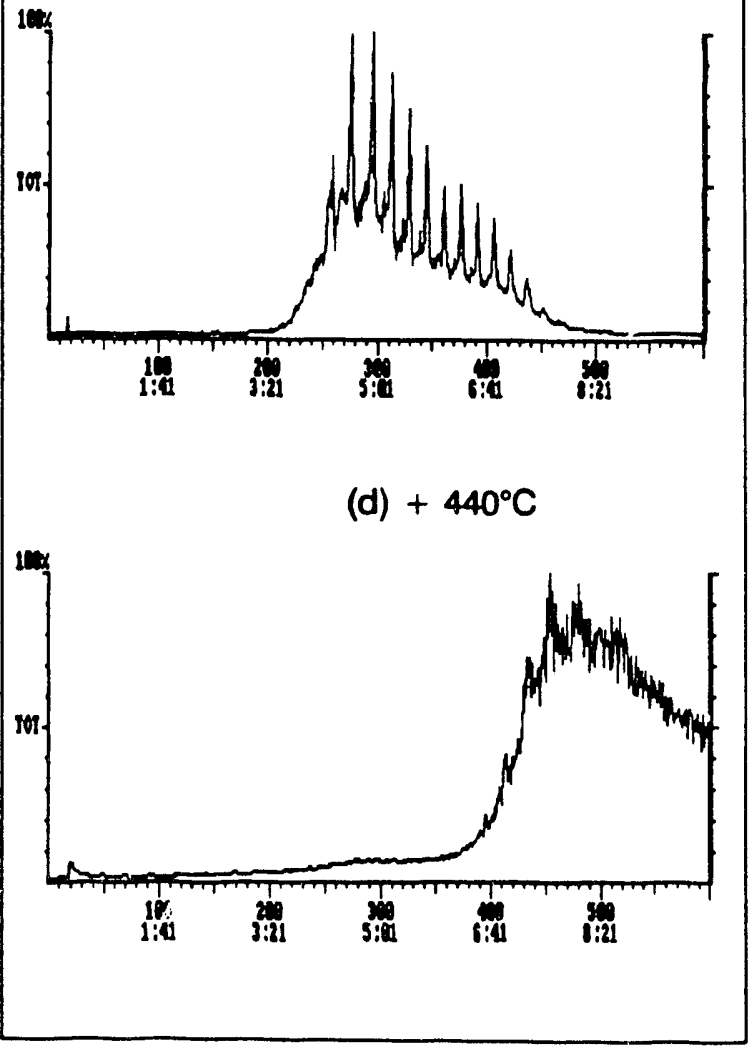
Recent advances in the study of structure/ property relationships have substantiated the fact that molecular weight is the principal characteristic of molecules in determining their overall thermodynamic properties and behavior. Properties such as volatility, viscosity, adsorption and solubility are all strong functions of molecular weight.

\section{Demonstration of Analytical and Engineering Data Methodology}

A key and unique feature of SO/NPX pertains to the advanced analytical approach for characterizing the feed and product fractions. In prior work ${ }^{(1-3)}$ it had been determined that thermodynamic properties of molecules correlated well with structural parameters 'n' (number of carbons), ' $z$ ', defined by the formula $\mathrm{C}_{n} \mathrm{H}_{2 n}+\mathrm{z} \mathrm{Nu} \mathrm{S}_{v} \mathrm{O}_{w}$, and ' $\mathrm{i}$ ' a non-integer number which relates to isomeric variations. ' $i$ ' is a strong function of entropic characteristics. ' $n$ ' and ' $z$ ' can be obtained from parent peak mass spectroscopy, while ' $i$ ' can be measured indirectly th:ough chromatographic retention times. The values for ' $u$ ', ' $v$ ', ' $w$ ', may be obtained from high resolution mass spec., atomic emission detection, sc-FTIR, or a combination of these. The development of the classifying system and correlating functions has been collectively labeled as the $\underline{Z}$-Based Structural Index Correlation method (Z-BASIC) ${ }^{(2)}$.

For chemical modeling, two levels of data are utilized. The first level of data is the gross characterization data consisting of elemental analysis, physical properties (such as refractive index and density), and boiling point distribution. The second level of data is focused on obtaining an analytical measure of the ' $n$ ', ' $z$ ' (and ' $u$ ', ' $v$ ', ' $w$ ') parameters of the Z-BASIC method as a function of molecular weight.
The Z-BASIC method allows, for the time, the ability to track the separation behavior of individual species from shale oil. This provides the analytical basis for process modeling on a molecular level.

A key factor supporting the viability of this approach is the virtual revolution in automated analysis technology of complex hydrocarbon mixtures such as shale oil. Coupled GC-MS-FTIR technologies available at the University of Utah Microanalysis and Reaction Chemistry Center were used to demonstrate the viability of using Z-BASIC for calculation of functions of molecular species.

Software programs were built to calculate all possible empirical formula combinations for each parent peak as well as statistical routines to determine the relative probability of each structure within that peak. This information is used in conjunction with GC-MS-FTIR and elemental and material balance data to calculate partition functions for a specific compound type.

Because separation processing is nondestructive, modeling may be based on fundamental thermodynamic behavior. What is required is the analyticai knowledge of the partitioning of individual species. This modeling is theoretically sound and allows for process scale-up on the order of 1,000 to 1 .

Figure 4 represents the information flow diagram for the analytical methodology. The flow diagram shows that detailed analytical data is used in concert with elemental analysis, property and specifications data and mass balances to provide a rigorous basis for process simulation. The simulation becomes the controlling function for modifying the process conditions and sequences to ob- 
tain the specification product. Where specifications cannot be met by separations processing alone, the comparison between actual compound type distribution and desired compound type distribution will help delineate any additional process required to improve the product quality. sess the following characteristics. The process must segregate molecular species with a maximum of overall partitioning. The process must be relatively inexpensive. The process should divide the process stream into major concentrates flows and should do more than just remove minor constituents from a

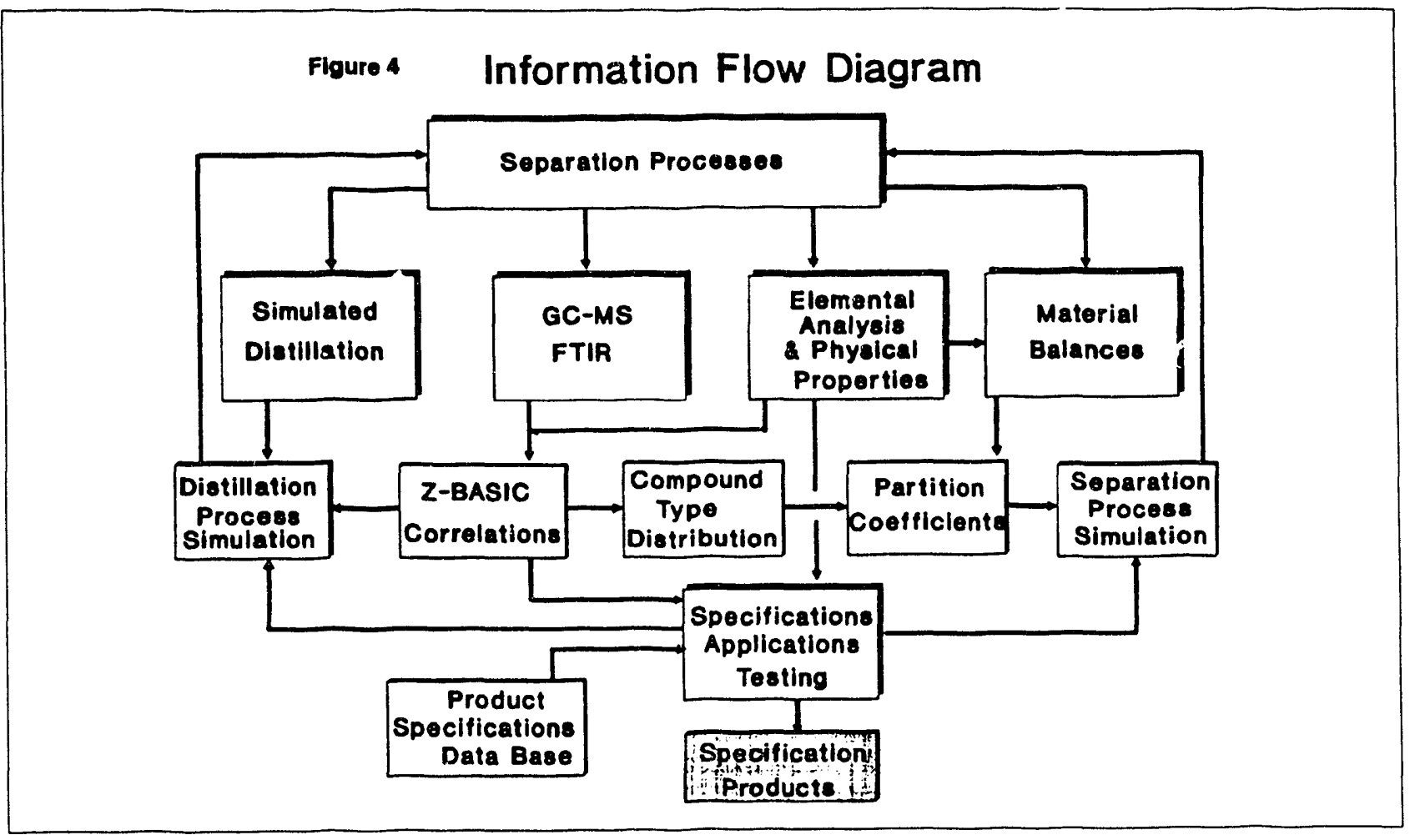

\section{Process Strategy}

The close relationship between molecular weight and boiling point dictates that the primary step in any shale oil NPX process sequence should be distillation. Theoretical arguments show that attempts at separating a broad M.W. range material on the basis of polarity, will suffer from lack of definitiveness between molecular weight and polarity effects. Thus, the first step in a SO/NPX process sequence is likely to be distillation.

The secondary step in the process is highly critical because this process must pos- mainstream. The process conditions should maintain low energy and/or material handling requirements. These are characteristics of liquid extraction processes. Secondary separation approaches for all four shale oil fractions were identified and successfully tested.

The tertiary separation process should possess the following characteristics. It should be selective and definitive in its partition functions. It should be geared to producing fractions which are either marketable or close to market quality. The general approach should be reasonably proven on a commercial scale. 
These are characteristics of adsorption processing. Tertiary separation approaches were identified and selected fractions from the secondary process were separated by the approaches.

Finishing processes may be a conventional or novel process which manufactures a marketable product from the concentrates produced in prior separations. These may include high efficiency distillation, catalytic processing, adsorption, precipitation, size exclusion, derivitization or other approaches.

The generalized separation sequence is shown in Figure 5. The sequence shows that shale oil is cut by molecular weight

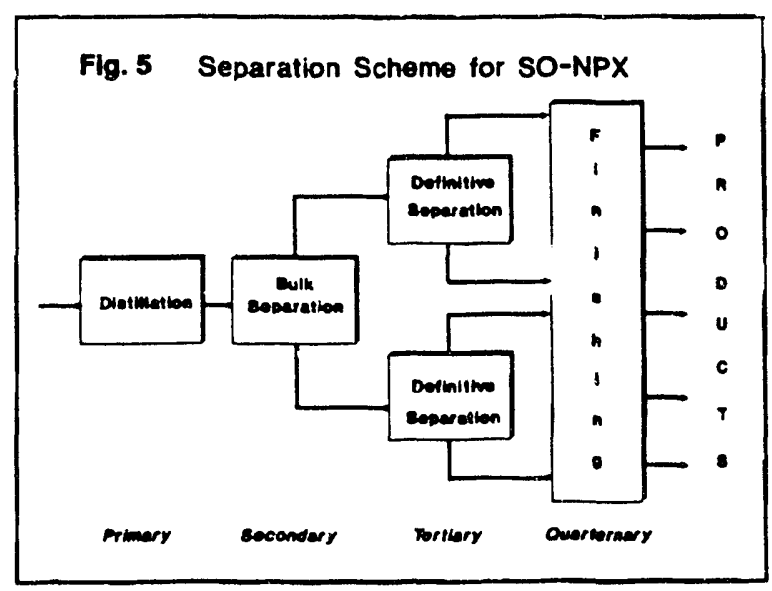

and polarity into bulk fractions which then undergo one or two processing steps to prepare products of market quality.

\section{Laboratory Results}

The laboratory separations were conducted in small-scale, batch-type processes and quantitative results must be further confirmed before publication. Laboratory conditions were designed to simulate commercially realistic conditions, e.g., solvent-to-oil and oil-to-adsorbent ratios of $1: 1$. The laboratory separations produced 16 specific concentrates covering four boiling ranges and four polarities. The overall yield and quality of the separations are given $\vdots_{1}$ Table 1.

The four major concentrates are labeled: white oils and waxes, aromatic oils, lowpolarity nitrogen compounds and highpolarity compounds. The weight percent of these concentrates, represented in the shale oil, are shown in the first column.

The elemental compositions of trese concentrates illustrates the differences achievable with relatively straight-forward and inexpensive separations. The white oils and waxes are extremely low in heteroatoms, including sulfur. Oxygen is calculated by difference and, therefore, is

\begin{tabular}{|c|c|c|c|c|c|c|c|}
\hline \multicolumn{8}{|c|}{$\begin{array}{c}\text { Table } 1 \\
\text { Summary of Elemental Composition } \\
\text { by Functional Concentrate }\end{array}$} \\
\hline Concentrate & $\begin{array}{l}\text { Wt \% of } \\
\text { Shale Oil }\end{array}$ & c & H & $\mathbf{N}$ & s & $\begin{array}{l}0 \\
\text { (Difi) }\end{array}$ & $\mathrm{H} / \mathrm{C}$ \\
\hline White Oils and Waxes & 13 & 85.7 & 13.8 & 0.05 & 0.02 & 0.26 & 1.92 \\
\hline Aromatic Oils & 22 & 87.0 & 12.1 & 0.2 & 0.6 & 0.5 & 1.66 \\
\hline $\begin{array}{l}\text { Low-Polartiy Nitrogen Com- } \\
\text { pounds }\end{array}$ & 35 & 83.6 & 10.4 & 3.2 & 0.7 & 3.4 & 1.47 \\
\hline $\begin{array}{l}\text { High-Polarity } \\
\text { Compounds }\end{array}$ & 30 & 82.7 & 10.6 & 2.8 & 0.8 & 3.2 & 1.52 \\
\hline
\end{tabular}


subject to a wider margin of error. The aromatic oil fraction is particularly interesting because it possesses a low nitrogen content while constituting a significant portion of the shale oil barrel.

The major fraction is the low-polarity nitrogen compounds. These materials are generally of a higher molecular weight and are thought to possess both carbazolic and aromatic nitrogen. The oxygen contained in these compounds is thought to be of lower polarity, typical of furanic, esteric or ketonic oxygen. The highpolarity compounds are extractable by polar solvents. While their elemental composition is similar to the previously discussed fraction, these materials are lower molecular weight and contain acidic, phenolic, nitrilic, pyrrolic and pyridinic functionalities.

\section{Shale Oil NPX Product Slate}

Based on our laboratory separations, a preliminary product slate for a shale oil NPX process output was constructed. This data is shown in Table 2.
The product slate includes oils, waxes, aromatic oils and aromatics for manufacture of sulfonates. The polar fraction includes acids, bases and resins. Functionalized intermediates are compounds containing nitrogen and oxygen which are thought to be of particular value as starting materials for derivatization to pharmaceuticals, medicinal chemicals and other pure compound systems.

Pure compounds are those with particularly high market value that may be isolable from shale oil with some subsequent purification. Target compounds include nitrogen compounds such as nitriles, pyridines and quinolines, amines and amides. Oxygen compounds include phenols and naphthols, carboxylic acids, ketones and alcohols.

The special applications concentrates represent mixtures with particular properties which make the concentrate marketable in its mixed form. Examples include industrial anti-microbials, coatings, wood preservatives, industrial surfactants and asphalt additives. Current projections suggest that less than $10 \%$ of

\begin{tabular}{|l|c|}
\hline \multicolumn{2}{|c|}{ Shale Oil Product Slate } \\
\hline \multicolumn{1}{|c|}{ Non-Polar Fractions } & Weight Percent Yields \\
\hline Waxes & 5.0 \\
\hline White Oils Polar Fractions & 13.3 \\
\hline Aromatic and Lubricating Oils & 30.5 \\
\hline Sulfonate Feedstocks & 11.7 \\
\hline Tar Acids/Bases Misc. Fractions & 4.0 \\
\hline Resins & 14.7 \\
\hline Functionalized Intermediates & 4.3 \\
\hline Pure Compounds & 0.7 \\
\hline \multicolumn{1}{|c|}{ Mpecial Applications Concentrates } & 10.3 \\
\hline Futis and Refinen Feeds & 5.5 \\
\hline
\end{tabular}


the shale oil barrel may require marketing as a fuel or refinery feed.

The majority of the products shown in Table 2, are targeted for conventional commodity markets for which the market is well established. The primary question which remains and must be addressed in future research and development relates to the quality of the shale oil product and what finishing steps will be required to render the shale oil product market acceptable. Other target products such as the functionalized intermediates and special-application concentrates may require significant market development. It is important to reemphasize that maximum economic enhancement of the commercial-sized shale oil facility, will occur most readily when a large percentage of the shale oil NPX product slate addresses large, well-established markets. One of the important discoveries of this work is that significant amounts of heteroatom containing compounds have potentially high value but these compounds are destroyed in conventional upgrading to synthetic crude oil.

The U. S. chemicals and commodity products markets were surveyed for market volume and recent price ${ }^{(4-8)}$. The markets into which the shale oil Native Product Extrac ion slate would be sold is listed in Table 3. The chemicals industry is generally situated in the Gulf Coast and Great Lakes areas with other concentrations on the East and West Coasts.

The data in Table 3 show that the market volume for white oils and lubricating oils is quite large whereas markets for functionalized intermediates and pure compounds are estimated at much lower values.

Table 3.

Demand and Value of Products

Output of SO/NPX $=170,000$ Tons/year $(3,000 \mathrm{bbl} / \mathrm{day})$

\begin{tabular}{|c|c|cc|c|c|c|}
\hline Product & $\begin{array}{c}\text { Market Volume } \\
\text { Tons/year }\end{array}$ & $\begin{array}{c}\text { Recent Price } \\
\text { \$/bblequivalent }\end{array}$ & $\begin{array}{c}\text { SO/NPX } \\
\text { Projected Yield } \\
\text { Wt. \% of Feed }\end{array}$ & $\begin{array}{c}\text { \% of } \\
\text { Market }\end{array}$ & $\begin{array}{c}\text { Revenua } \\
\text { s/feed-bbl }\end{array}$ \\
\hline White Oils & $4,575,000$ & 84 & Ref (4) & 13.3 & 0.5 & 11.2 \\
\hline Waxes & 882,000 & 133 & Ref (4) & 5.0 & 1.0 & 6.6 \\
\hline $\begin{array}{c}\text { Aromaticl } \\
\text { Lubricating Oils }\end{array}$ & $9,526,365$ & 60 & Ref (4) & 30.5 & 0.5 & 18.3 \\
\hline Sulfonate Feeds & 333,900 & 142 & Ref (5) & 11.7 & 5.9 & 16.6 \\
\hline $\begin{array}{c}\text { Tar Acids } \\
\text { and Bases }\end{array}$ & 830,000 & 210 & Ref (6) & 4.0 & 0.8 & 8.4 \\
\hline Resins & 542,000 & 120 & Ref (7) & 14.7 & 4.6 & 17.6 \\
\hline $\begin{array}{c}\text { Functionalized } \\
\text { Intermediates }\end{array}$ & 130,000 & 178 & Ref (7) & 4.3 & 5.6 & 7.6 \\
\hline $\begin{array}{c}\text { Special } \\
\text { Application } \\
\text { Concentrates }\end{array}$ & 500,000 & 28 & Ref (6) & 10.3 & 3.5 & 2.9 \\
\hline Pure Compounds & 200,000 & 135 & Ref (7) & 0.7 & 0.6 & 0.9 \\
\hline $\begin{array}{c}\text { Fusis and } \\
\text { Refinery Feeds }\end{array}$ & 1 large & 15 & Ref (8) & 5.5 & & 0.8 \\
\hline \begin{tabular}{c} 
Totals \\
\hline
\end{tabular} & & & & 100 & & $\$ 90.90 / \mathrm{bbl}$ \\
\hline
\end{tabular}


The product values range from a high of approximately $\$ 200 / \mathrm{bbl}$ to a low of less than $\$ 20 / b b l$. In general, the product value and the market volume show an inverse relationship consistent with earlier observations made by Sinor ${ }^{(6)}$. Where uncertainties exist between the projected shale oil product slate and the existing market, a conservative approach was taken so as not to overinflate either the potential market capacity or the projected product price.

Table 3 also shows the percent of the market which a 170,000 ton/year facility would require. In all cases, the percent $o_{i}^{i}$ the market is less than $10 \%$, and for approximately $60 \%$ of the barrel, the output represents less than $2 \%$ of the market. From this information, we conclude that market limitations will not be a serious problem for a single $3,000-8,000 \mathrm{bbl} /$ day SO/NPX facility, and it may prove that the actual markets are substantially greater than those conservatively surveyed and depicted in Table 3.

The final column in Table 3 represents the revenue contribution of each of the product streams toward the weighted average selling price. These values are obtained by simply multiplying the sales price per barrel times the weight fraction of the product produced from shale oil. As can be seen, the total product value receives significant contributions from a half-dozen products including both polar and non-polar species reinforcing the concept that shale oil contains large concentrations of valuable polar and nonpolar constituents and that extraction upgrades both sides of the separation streams.

\section{Development of Market Strategy}

A critical feature of the SO/NPX process strategy is the target markets for the products. In general, shale oil-derived products will be either substitutes for products currently in the marketplace, or they will be unconventional products for which shale oil represents a unique source of material.

The process strategy is designed to maximize the amount of conventional products in order to reduce difficulties with market acceptance. In addition, the strategy is designed to develop a highvalue option for the entire barrel, if possible. The opportunity to achieve this latter objective has been significantly enhanced by the present study.

\section{Market Classifications}

The SO/NPX product markets can be broadly classified in four categories:

\section{1 - Finished Products}

Finished products are those which meet market specifications and are ready for sale to users. These products include solvents, lube oils, waxes, fuels, carbon products, pure compounds and other specification materials.

\section{2 - Broad-Range Feedstocks}

These products represent concentrates to be fed to downstream process plants. These concentrates would be purchased by chemical products finishing manufacturers for manufacture into a variety of products. Examples include white oils, aromatic oils and resins.

\section{3 - Chemical Intermediates}

Chemical intermediates are pure compounds or fractions which are convertible in one or more chemical process steps to finished products such as plastics, fibers and polymers. Examples are non-polar aromatics for the manufacture of sul- 
fonate and functionalized intermediates for derivitization or polymerization.

\section{4 - By-products and unconventional products}

By-products streams include asphaltic products, additives, inexpensive pitches or sealants, fuels or refinery feedstocks. An important characteristic of nondestructive separations is that in the process of separating primary products, by-products are upgraded as well. Unconventional products are those of unique origins to shale oil and hold high potential for innovative developments.

\section{Market Size}

The current U.S. market for oils and wax products is about $500,000 \mathrm{bbls} /$ day. For all chemicals including chemical intermediates, solvents, finished industrial products and finished consumer products, the total demand is approximately 2-million bbls/day. A projected output of a shale oil Native Products Extraction facility is on the order of $3,000-8,000$ bbls/day, a small number in relationship to the total market demand. The market strategy will, therefore, consist of targeting markets where a superior or unique product can be produced from shale oil at a cost competitive with the alternatives.

\section{Competition}

The traditional source of commodity chemicals is crude oil, or in certain cases, coal-derived tars and liquids. The competition is therefore, directly tied to the price uniformity and availability of crude oil. For shale oil to compete with crude oil, it must contain higher concentrations of selected products or afford new products not readily manufactured from crude. The projected product slate shows both of these advantages.

The availability of shale oil in the Rocky Mountain West may spawn chemicals manufacturing facilities in the west. Products from a SO/NPX technology will be reliable and consistent, and would successfully compete with the ever-changing traditional supply of hydrocarbon products. Shale oil is also a secure, domestic supply of feedstock.

A physical lifetime of 30-40 years would be long enough to justify the capital investment of a dedicated chemical plant designed to process the shale oil output. Once the value has been added to the product, transportation and distribution costs become less of an economic factor.

\section{Unique Capabilities}

The Shale Oil Native Products Extraction technology is unique in several important characteristics. First, the source of material is unique and offers opportunities for manufacture of selected products in greater concentrations, superior properties or simpler processing pathways compared to those available from conventional crude oil.

Second, the technology developed by JWBA is unique in its approach in that it is derived from fundamental thermodynamics and chemometric analysis of the shale oils. This fundamental approach provides high assurances that important market opportunities are not overlooked.

Third, successful commercialization of SO/NPX, based on a single source feedstock, will guaranty a long-term, consistent supply to the buyer. In the long run, this may prove an important competitive advantage in relationship to the 
variability in composition and price that may emerge in the petrochemicals industry.

\section{Market Penetration}

The primary marketing thrust will be to develop long-term supply contracts with by summing the costs for the unit operations. Costs for unit operations were determined from analogy to commercially-practiced technologies. Results are given in Table 4.

Based on the material balance used to

\begin{tabular}{|c|c|c|c|c|}
\hline \multicolumn{5}{|c|}{$\begin{array}{c}\text { Table } 4 \\
\text { Estimated Process Costs for SO/NPX } \\
\text { (Basis: } 1,065,000 \text { bbl/year) }\end{array}$} \\
\hline \multicolumn{2}{|r|}{ Unit } & $\begin{array}{c}\text { Process Cost } \\
\text { \$/bbl }\end{array}$ & $\begin{array}{l}\text { Throughput } \\
\text { bbl/yr }\end{array}$ & $\begin{array}{c}\text { Operating Costs } \\
S M / Y T\end{array}$ \\
\hline 1. & Distillation & 1.5 & $1,065,000$ & 1.60 \\
\hline 2. & $\begin{array}{l}\text { Liquid-Liquid } \\
\text { Extraction }\end{array}$ & 2.7 & $1,065,000$ & 2.88 \\
\hline 3. & Adsorption & 4.2 & 958,500 & 4.03 \\
\hline 4. & Dewaxing & 3.2 & 95,850 & 0.31 \\
\hline 5. & High-Efficiency Separation & 4.5 & 60,705 & 0.27 \\
\hline 6. & Hydrofinishing & 2.1 & 777,400 & 1.63 \\
\hline 7. & $\begin{array}{l}\text { Miscellaneous } \\
\text { (Filtration, Precipitation, } \\
\text { Crystallization, etc.) }\end{array}$ & 4.0 & $1,065,000$ & 4.26 \\
\hline \multicolumn{4}{|c|}{ Annual Manufacturing Costs } & $\$ 14.98 \mathrm{M}$ \\
\hline
\end{tabular}

existing industry already manufacturing and selling finished products. The rnarket strategy will consist of developing commercial quality products that can successfully compete on a cost basis with petroleum-derived feedstocks.

Development of market opportunities will involve identifying suitable buyers and initiating the discussions with them as soon as specific products are available for inspection and commercial qualification. Because of unique and advantageous structures present in shale oil, new product development affords attractive R\&D opportunities.

\section{Economic and Profitability Estimates}

Preliminary process costs for manufacture of the product slate were determined calculate data in Table 3, the capacity of each unit operation was determined. The weighted contribution to total process costs was determined by multiplying these two values. Results show annual operating costs at $\$ 14.98 \mathrm{M}$, or about $\$ 14 / \mathrm{bbl}$ (fob).

In order to adjust costs for market location, a charge of $\$ 5 / \mathrm{bbl}$ was added for transportation and distribution costs. This allows for an average radius of about 750 miles. Higher value products, e.g., $\$ 100 / \mathrm{bbl}$ could be shipped further. Lower value products, e.g., asphalt, would be used locally or regionally. The specific costs for distribution must be assessed in future studies when the product slate is better known.

Capital costs were estimated by summing 
the unit costs, weighted for throughput capacity. The capital and operating costs, combined with projected revenues were used to make a profitability estimate.

The profitability estimates are based on a $100 \%$ equity case, using a $10 \%$ discount rate. The impact of various debt-to-equity ratios can be estimated by multiplying the debt to equity ratio times the DCF-ROI calculated for the $100 \%$ equity case. assuming the interest rate is equivalent to the discount rate.

Figure 6 (a-d) summarize the projected economics of a shale oil NPX project. Part (a) shows the capital cost and return on investment as a function of capacity. For purposes of this analysis, the per barrel operating costs were assumed to be insensitive to capacity, although one would expect that increased capacity would also reduce the operating costs if for no other reason than a reduction in the per-barrel interest charge.

Results show that an anticipated real ROI of $25-4.5 \%$ is expected. This is a substantial return for the processing venture and leads to the immediate conclusion that there is significant economic attractiveness in the SO/NPX technology.

Because the ROI is affected by the projected revenues obtained, a sensitivity analysis was performed to ascertain the effect of product price on ROI. Part (b) of Figure 6, shows these results and shows that a significant return on investment could still be made, even if the weighted average product price was as low as $\$ 65 / \mathrm{bbl}$.

An important objective of the current study was to ascertain the economic enhancement of a shale oil venture using NPX technology as a means of moving shale oil into the high-value product market. Using the base case of 5,000 bbl/day and an average product value of $\$ 90.9 / \mathrm{bbl}$, sensitivity of ROI to the cost of raw shale oil was determined. Results are shown in part (c) and show that a significant return on investment could be made, even if shale oil costs were $\$ 40 / \mathbf{b b l}$. Production of raw shale oil at $\$ 40 / \mathrm{bbl}$ is in the economically feasible region for many proposed shale oil technologies.

The relationship between the capacity of the facility and the cost of raw shale oil on return on investment is illustrated in part (d). As plant capacity increases, the price one can afford to pay for raw shale oil and maintain a given return on investment also increases. The results of Figure 6 demonstrate that SO/NPX has the potential for significant economic enhancement of a shale oil production facility and that the maximum economic enhancement comes from the largest SO/NPX facility that the market will bear.

\section{Future Development}

Future development must now focus on the following areas:

a) Engineering development of the SO/NPX technology;

b) Production of samples which can be used for market inspection and evaluation;

c) Optimization of SO/NPX as to scale, product slate and markets;

d) Scaled development of the SO/NPX venture in concert with a shale oil production facility. 


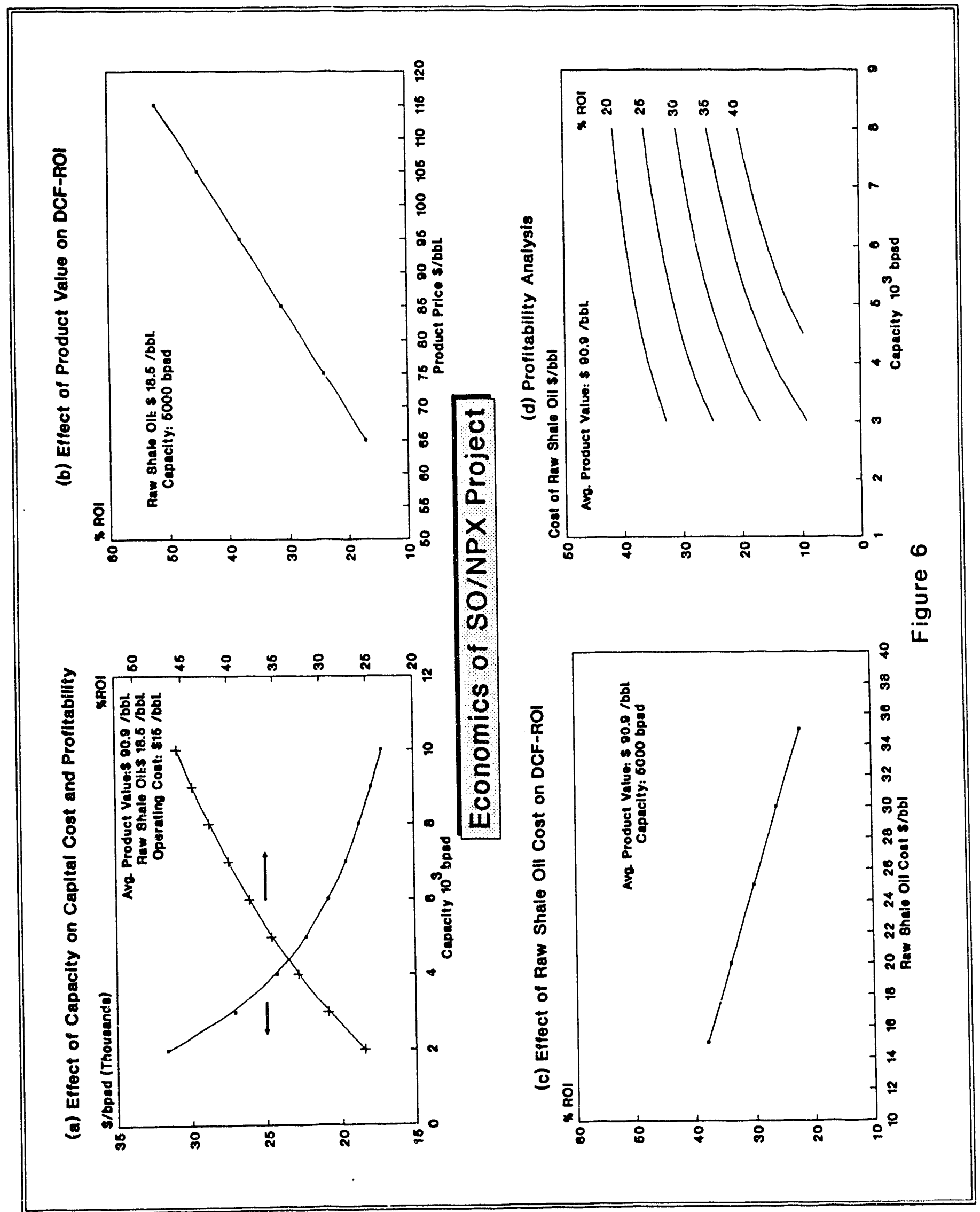




\section{Conclusions}

Results of the planning and feasibility study have shown that SO/NPX is technically feasible, produces products which promise high market value and shows significant economic potential. Market limitations are not significant for an SO/NPX facility of less than 8,000 bbl/day. The economic impact of SO/NPX on commercial production economics is significant. SO/NPX technology promises to be a breakthrough technology, making oil shale commercialization economic under normal petroleum and petroleum product pricing conditions.

\section{References}

1. Bunger, J.W., Devineni, P., Russell, C.P., and Oblad, A.G., "Structure of Future Jet Fuels - A Model for Determining Physical and Chemical Properties from Molecular Structure", Preprints, Division of Petroleum Chemistry, 30 (1), 1987.

2. Devineni, P., "A Model for Correlating Properties with Molecular Structure and Its Application to Fuel/Hydrocarbon Processing", Ph.D. Thesis, Dept. of Fuels Engineering, University of Utah, 1989.

3. Devineni, P., Bunger, J.W., and Rus- sell, C.P., "Prediction of Optimum Structure for Jet Fuel Components Using the Z-BASIC Method", Preprints, Division of Petroleum Chemistry, 1989.

4. 1988 Report on U.S. Lubricating Oil Sales - National Petroleum Refiners Association.

5. Chemical Economics Handbook SRI International, \#543.8050A, 1987.

6. Sinor, J.E., "Niche Market Assessment for a Small Scale Western Oil Shale Project", Final Report, U.S. DoE, 1989.

7. United States Production and Sales, 1988 - Synthetic Organic Chemicals - U.S. International Trade Commission Publication.

8. Chemical Marketing Reporter, August 1990.

\section{Acknowledgments}

The support of Dr. Ray Zahradnik and his early recognition of the economic potential of the NPX strategy is greatly appreciated. The financial support of Occidental Oil Shale, Inc., and the U. S. Department of Energy is gratefully acknowledged. 


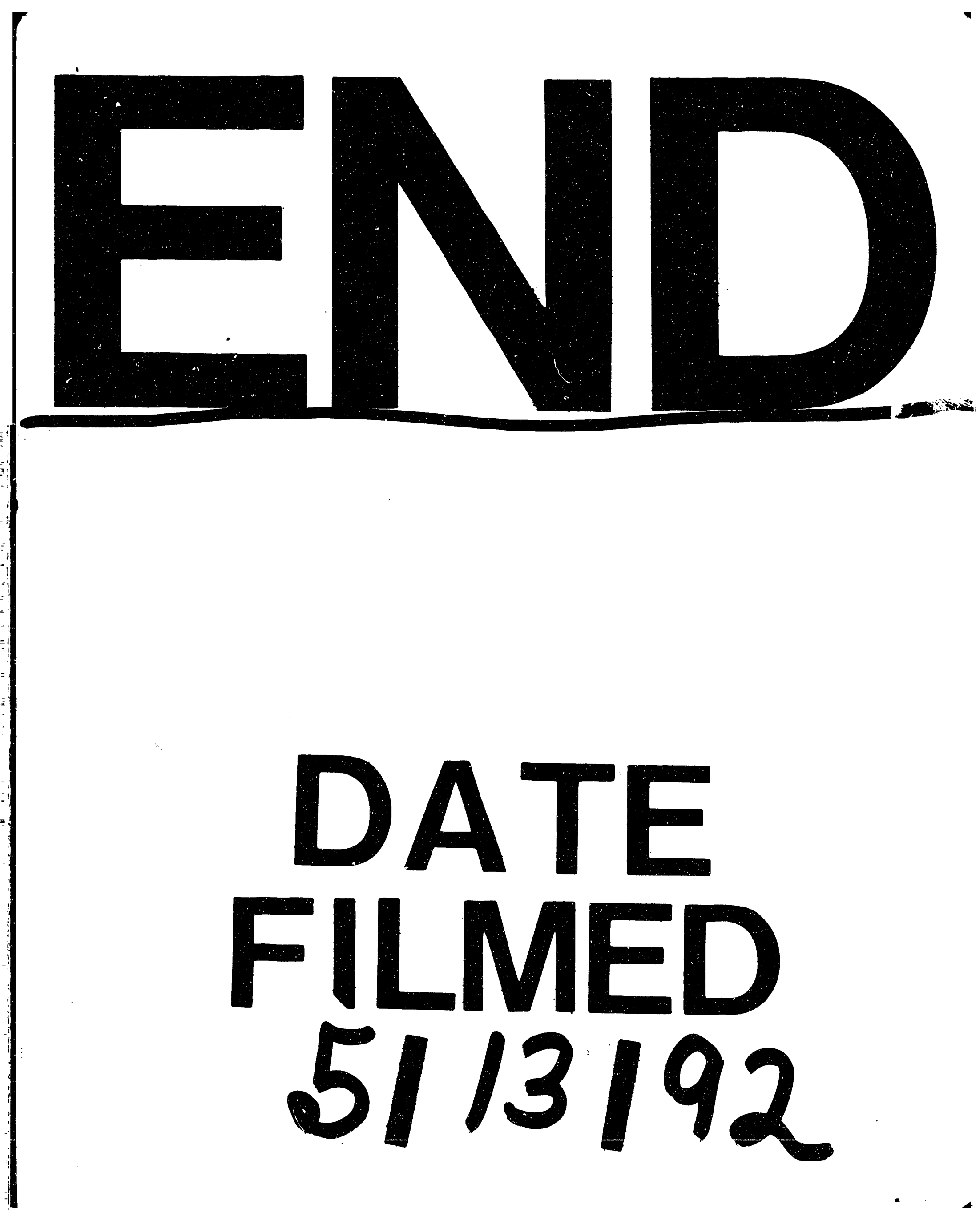


